\title{
Indonesia dalam Menghadapi Pandemi Covid-19
}

\author{
Ririn Noviyanti Putri \\ Universitas Kader Bangsa \\ Correspondence email: ririnnoviyanti95@gmail.com
}

\begin{abstract}
Abstrak. Indonesia pada terkena dampak wabah baru yakni virus covid-19. Covid-19 telah menjadi pandemi dikarenakan jumlah kasusdi Indonesia yang terkonfirmasi terus meningkat, maka Indonesia sangat memerlukan tata cara pengendalian dan pencegahan pandemi covid-19. Tulisan ini bertujuan untuk menganalisa langkah-langkah yang telah dilakukan Indonesia dalam menghadapi covid-19. Metode yang digunakan oleh penulis adalah studi kepustakaan (literature review). Hasil yang didapat bahwa Indonesia telah banyak menerapkan berbagai kebijakan dalam pengendalian dan pencegahan covid-19. Namun, kebijakan tersebut harus didukung juga dengan kesadaran masyarakat serta sistem kesehatan yang baik.
\end{abstract}

Kata kunci: Covid-19; Indonesia; Pandemi.

Abstract. Indonesia was affected by a new epidemic namely the covid-19 virus. Covid-19 has become a pandemic because the number of confirmed cases in Indonesia continues to increase, so Indonesia urgently needs procedures for controlling and preventing the covid-19 pandemic. This paper aims to analyze the steps Indonesia has taken in dealing with covid-19. The method used by the authors is literature review. The results obtained that Indonesia has implemented many policies in controlling and preventing covid-19. However, the policy must also be supported by public awareness and a good health system.

Keywords: Covid-19; Indonesian; Pandemic.

\section{PENDAHULUAN}

Akhir tahun 2019 tepatnya pada bulan desember, dunia dihebohkan dengan sebuah kejadian yang membuat banyak masyarakat resah yaitu dikenal dengan virus corona (covid-19). Kejadian tersebut bermula di Tiongkok, Wuhan (Yuliana, 2020). Pada awalnya virus ini diduga akibat paparan pasar grosir makanan laut huanan yang banyak menjual banyak spesies hewan hidup. Penyakit ini dengan cepat menyebar di dalam negeri ke bagian lain China (Dong et al., 2020). Tanggal 18 Desember hingga 29 Desember 2019, terdapat lima pasien yang dirawat dengan Acute Respiratory Distress Syndrome (ARDS) (Ren L et al., 2020). Sejak 31 Desember 2019 hingga 3 Januari 2020 kasus ini meningkat pesat, ditandai dengan dilaporkannya sebanyak 44 kasus (Susilo et al., 2020).

Munculnya 2019-nCoV telah menarik perhatian global, dan Pada 30 Januari WHO telah menyatakan COVID-19 sebagai darurat kesehatan masyarakat yang menjadi perhatian internasional (Dong et al., 2020). Penambahan jumlah kasus COVID-19 berlangsung cukup cepat dan sudah terjadi penyebaran antar negara. Sampai dengan tanggal 25 Maret 2020, dilaporkan total kasus konfirmasi 414.179 dengan 18.440 kematian (CFR 4,4\%) dimana kasus dilaporkan di 192 negara/wilayah. Diantara kasus tersebut, sudah ada beberapa petugas kesehatan yang dilaporkan terinfeksi (Kemenkes RI, 2020).

Coronavirus Disease 2019 (COVID-19) adalah penyakit jenis baru yang belum pernah diidentifikasi sebelumnya pada manusia. Virus penyebab COVID-19 ini dinamakan Sars-CoV-2. Virus corona adalah zoonosis (ditularkan antara hewan dan manusia).
Adapun, hewan yang menjadi sumber penularan COVID-19 ini masih belum diketahui. Berdasarkan bukti ilmiah, COVID-19 dapat menular dari manusia ke manusia melalui percikan batuk/bersin (droplet), Orang yang paling berisiko tertular penyakit ini adalah orang yang kontak erat dengan pasien COVID-19 termasuk yang merawat pasien COVID-19 (Kemenkes RI, 2020). Tanda dan gejala umum infeksi covid-19 termasuk gejala gangguan pernapasan akut seperti demam, batuk, dan sesak napas. Masa inkubasi rata-rata adalah $5-6$ hari dengan masa inkubasi demam, batuk, dan sesak napas. Pada kasus yang parah, covid-19 dapat menyebabkan pneumonia, sindrom pernapasan akut, gagal ginjal, dan bahkan kematian (Tosepu et al., 2020).

Indonesia adalah negara berkembang dan terpadat keempat di dunia, dengan demikian diperkirakan akan sangat menderita dan dalam periode waktu yang lebih lama. Ketika coronavirus novel SARS-CoV2 melanda Cina paling parah selama bulan-bulan Desember 2019 Februari 2020. Pada 27 Januari 2020, Indonesia mengeluarkan pembatasan perjalanan dari provinsi Hubei, yang pada saat itu merupakan pusat dari COVID19 global, sementara pada saat yang sama mengevakuasi 238 orang Indonesia dari Wuhan. Presiden Joko Widodo melaporkan pertama kali menemukan dua kasus infeksi COVID-19 di Indonesia pada 2 Maret 2020 (Djalante et al., 2020). Pasien yang terkonfirmasi covid-19 di Indonesia berawal dari suatu acara di Jakarta dimana penderita kontak dengan seseorang warga Negara asing (WNA) asal Jepang yang tinggal di Malaysia. Setelah pertemuan tersebut penderita mengeluh demam, batuk dan sesak nafas (WHO, 2020). 
WHO mengumumkan COVID-19 pada 12 Maret 2020 sebagai pandemic. Jumlah kasus di Indonesia terus meningkat dengan pesat, hingga Juni 2020 sebanyak 31.186 kasus terkonfirmasi dan 1851 kasus meninggal (PHEOC Kemenkes RI, 2020). Kasus tertinggi terjadi di Provinsi DKI Jakarta yakni sebanyak 7.623 kasus terkonfirmasi dan 523 (6,9\%) kasus kematian (PHEOC Kemenkes RI, 2020). WHO mengeluarkan enam strategi prioritas yang harus dilakukan pemerintah dalam menghadapi pandemic covid-19 pada tangal 26 Maret, yang terdiri dari Perluas, latih, dan letakkan pekerja layanan kesehatan; Menerapkan sistem untuk dugaan kasus; Tingkatkan produksi tes dan tingkatkan layanan kesehatan; Identifikasi fasilitas yang dapat diubah menjadi pusat kesehatan coronavirus; Mengembangkan rencana untuk mengkarantina kasus; dan Refokus langkah pemerintah untuk menekan virus (WHO, 2020).

Wabah ini telah ditetapkan sebagai darurat kesehatan global. Virus ini sempat membuat semua kegiatan sehari-hari manusia terhambat. Karantina saja mungkin tidak cukup untuk mencegah penyebaran virus COVID-19 ini, dan dampak global dari infeksi virus ini adalah salah satu yang semakin memprihatinkan (Sohrabi et al., 2020). Pemerintah Indonesia telah melakukan banyak langkah-langkah dan kebijakan untuk mengatasi permasalahan pandemic ini. Salah satu langkah awal yang dilakukan oleh pemerintah yaitu mensosialisasikan gerakan Social Distancing untuk masyarakat. Langkah ini bertujuan untuk memutus mata rantai penularan pandemi covid-19 ini karena langkah tersebut mengharuskan masyarakat menjaga jarak aman dengan manusia lainnya minimal 2 meter, tidak melakukan kontak langsung dengan orang lain serta menghindari pertemuan massal (Buana D.R, 2020). Namun, pada kenyataannya langkah-langkah tersebut tidak disikapi dengan baik oleh masyarakat, sehingga jumlah kasus terus meningkat. Di samping itu, pelayanan kesehatan di Indonesia dan SDM kesehatan yang ada dalam menangani kasus pandemic covid-19 ini juga belum memadai sedangkan kasus terus melonjak naik. Berdasarkan latar belakang dari tulisan ini maka penulis ingin melihat bagaimana Indonesia dalam menghadapi pandemic covid-19 yang terjadi saat ini.

\section{METODE}

Tulisan ini di analisis dengan analisis kajian studi kepustakaan (literature review) terkait dengan masalah pandemi covid-19. Studi kepustakaan merupakan studi yang objek penelitiannya berupa karya-karya kepustakaan baik berupa jurnal ilmiah, buku, artikel dalam media massa, maupun data-data statistika. Literatur review ini digunakan untuk mengetahui langkah-langkah yang dilakukan Indonesia dalam menghadapi pandemi covid-19 yang dilihat dari sudut pandang kebijakan maupun sistem kesehatan di Indonesia.

\section{HASIL DAN PEMBAHASAN}

\section{Langkah-Langkah yang Telah di Lakukan Indonesia}

Indonesia saat ini terkena dampak pandemi virus baru, bahkan bukan hanya di Indonesia tetapi secara global di berbagai Negara telah terkena dampak yang sangat hebat dari virus ini. World Health Organization memberi nama virus ini Severe Acute Resporatory Syndrome coronavirus-2 (SARS-CoV-2) dengan nama penyakitnya yakni Coronavirus disease 2019 (Covid-19) (WHO, 2020). Pandemi covid-19 ini akan berdampak secara sosial dan ekonomi. Dalam hal ini Indonesia harus bersiap siaga dalam menghadapinya terutama dalam hal sistem kesehatan yang ada.

Status siaga darurat adalah keadaan ketika potensi ancaman bencana sudah mengarah pada terjadinya bencana, yang ditandai dengan adanya informasi peningkatan ancaman berdasarkan sistem peringatan dini yang diberlakukan dan pertimbangan dampak yang akan terjadi di masyarakat (Kemenkes RI, 2018). Indonesia perlu siaga dan tanggap dikarenakan corona virus disease 2019 (Covid-19) ini telah ditetapkan sebagai pademi. Dampak yang ditimbulkan akan sangat meluas, mulai dari politik, ekonomi, sosial, budaya, pertahanan, dan keamanan, serta kesejahteraan masyarakat. Dalam hal ini Indonesia tidak bisa hanya mengandalkan petugas kesehatan dan sarana prasarana saja, tetapi juga harus melibatkan msyarakat serta sistem kesehatan yang mendukung.

Sistem kesehatan menurut World Health Organization (WHO) adalah "sebuah kegiatan yang bertujuan dalam mempromosikan, memulihkan, atau menjaga kesehatan". Indonesia adalah negara kepulauan terbesar di dunia, yang memiliki penduduk lebih dari 240 juta jiwa. Indonesia juga termasuk status ekonomi yang berpenghasilan menengah ke bawah (Putri R.N, 2019). Dengan terjadinya pandemi covid-19 ini, maka dampak ekonomi sangat dirasakan oleh Indonesia dikarenakan kasus yang terkonfirmasi terus meningkat (Gambar 1).

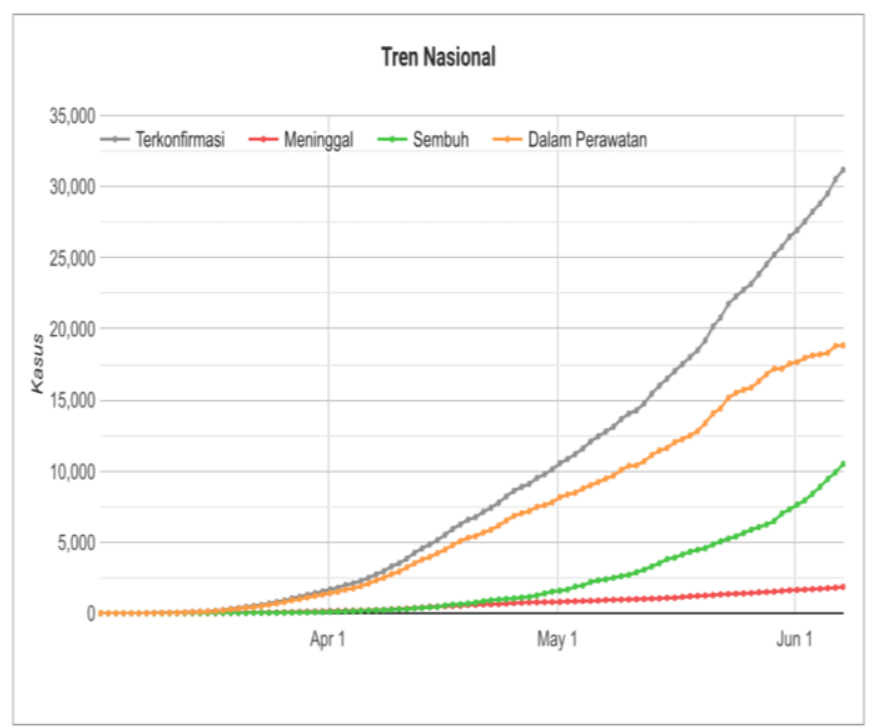

Gambar 1. Grafik Perkembangan Covid-19 (Per Juni 2020) 
Tabel 1. Persentase Kasus Kematian Tertinggi di Indonesia (Per Juni 2020)

\begin{tabular}{|l|c|c|c|c|}
\hline \multicolumn{1}{|c|}{ PROVINSI } & KASUS & KEMATIAN & \multicolumn{3}{|c|}{ PERSENTASE KEMATIAN } \\
\hline Kalimantan Selatan & 1.033 & 90 & $8,7 \%$ & \\
\hline Jawa Timur & 5.318 & 429 & $8,1 \%$ & \\
\hline Banten & 954 & 69 & $7,2 \%$ & \\
\hline DKI Jakarta & 7.623 & 523 & $6,9 \%$ & \\
\hline Jawa Barat & 2.319 & 154 & $6,6 \%$ & \\
\hline Jawa Tengah & 1.455 & 71 & $4,9 \%$ & \\
\hline Sulawesi Selatan & 1.668 & 75 & $4,5 \%$ & \\
\hline Sumatera Selatan & 1.029 & 35 & $3,4 \%$ & \\
\hline Nusa Tenggara Barat & 685 & 13 & $1,9 \%$ & \\
\hline Papua & 858 & 7 & $0,8 \%$ & \\
\hline
\end{tabular}

Berdasarkan grafik tersebut dapat dilihat bahwa kasus yang terkonfirmasi terus meningkat. Potensi pandemi COVID-19 menuntut pengawasan ketat dan pemantauan yang sedang berlangsung secara akurat melacak dan berpotensi memprediksi adaptasi host, evolusi, transmisibilitas, dan patogenisitas di masa depan. Faktor-faktor ini pada akhirnya akan mempengaruhi angka kematian dan prognosis, maka sangat diperlukan panduan pengendalian dan pencegahan penyakit ini (Sohrabi et al., 2020)

Pada 27 Januari 2020, Kebijakan yang pertama dilakukan oleh Indonesia adalah mengeluarkan pembatasan perjalanan dari pusat covid-19 yaitu provinsi Hubei. Pada saat yang sama Indonesia juga mengevakuasi 238 orang Indonesia dari Wuhan. Setelah terjadi laporan awal kasus yang terinfeksi, Indonesia mulai menyadari kekejaman situasi saat itu serta mengeluarkan berbagai kebijakan dan tindakan untuk mengatasi pandemic covid-19, termasuk menunjuk 100 rumah sakit umum dalam negeri sebagai Rumah Sakit Rujukan pada 3 Maret 2020. Sedangkan pada 8 Maret 2020, Indonesia meningkatkan jumlah Rumah Sakit Rujukan menjadi 227 untuk mengatasi jumlah pasien COVID-19 yang terus meningkat. Akan tetapi, upaya tersebut tidak dapat mengatasi permasalan pandemi covid-19, dikarenakan jumlah korban terus meningkat dengan cepat (WHO, 2020).

Pemerintah Indonesia juga menerapkan langkah social distancing bagi masyarakat serta memberikan prinsip protocol kesehatan, yaitu gunakan masker, cuci tangan/hand sanitizer, jaga jarak/hindari kerumunan, meningkatkan daya tahan tubuh, konsumsi gizi seimbang, kelola penyakit comorbid dan memperhatikan kelompok rentan serta perilaku hidup bersih dan sehat. Namun pada kenyataannya banyak masyarakat yang tidak mematuhi protokol kesehatan yang diberikan dalam menghadapi pandemi covid-19 (Buana D.R., 2020).

Selain itu juga, terdapat keputusan Presiden Indonesia mengenai satuan tugas untuk respon cepat covid-19. Pada akhir Maret 2020, Satuan Tugas Indonesia untuk COVID-19 (Gugus Tugas Percepatan Penanganan COVID-19) mengeluarkan Pedoman untuk
Respon Cepat Medis dan Aspek Kesehatan Penanganan COVID-19 di Indonesia. Panduan ini menargetkan tenaga medis dan masyarakat umum dalam hal menginformasikan cara untuk mengurangi dampak dan tingkat kematian. Informasi termasuk protokol untuk tes cepat menggunakan RDT, pengujian laboratorium, penanganan pasien, dan sarana penjangkauan/komunikasi. Protokol untuk pengujian cepat dan pengujian laboratorium mengenali tiga tingkat risiko: tanpa gejala, orang di bawah pengawasan (ODP/Orang Dalam Pemantauan), dan pasien di bawah pengawasan. Tes ini melibatkan isolasi orang yang dicurigai, pengujian cepat, dan pada akhirnya, jika diperlukan, PCR (Djalante et al., 2020).

Sedangkan Kebijakan yang baru-baru ini yang dilakukan pemerintah yaitu PSBB (Pembatasan Sosial Beskala Besar). PSBB tertuang dalam Peraturan Pemerintah No 21 Tahun 2020 tentang PSBB dalam rangka percepatan penanganan coronavirus disease (Covid-19). Beberapa hal yang dibatasi selama PSBB, diantaranya aktivitas sekolah dan tempat kerja, kegiatan keagamaan, kegiatan di fasilitas umum, kegiatan sosial dan budaya, serta operasional transportasi umum (Kemenkes RI, 2020). Namun, kenyataannya masyarakat banyak yang tidak mematuhi peraturan yang ada. maka dari itu meskipun pemerintah telah banyak berupaya untuk memutus mata rantai covid-19 tetapi harus didukung dan memerlukan kesadaran yang lebih dari masyarakat untuk bersama-sama memutus mata rantai covid-19.

\section{Pelayanan Kesehatan}

Wabah covid-19 ini tidak hanya meresahkan masyarakat saja, tetapi pelayanan kesehatan merupakan ujung tombak penanganan covid-19 ini. Kelompok resiko yang paling rentan terkena covid-19 ini asalah orang yang tinggal di daerah terpencil yang mana sistem kesehatan dan akses ke layanan kesehatan masih terbatas.

Di Indonesia, kapasitas sistem kesehatan berada di bawah kapasitas untuk mengatasi pandemi covid-19. Upaya yang dilakukan oleh Fasilitas Layanan Kesehatan dalam menghadapi covid-19 ini diantaranya, memperkuat sistem kesehatan agar menjamin rumah sakit memiliki kapabilitas yang baik dalam menangani pasien, pemanfaatan jejaring/ online medicine treatment (pengobatan online), pemanfaatan sistem/ platform telemedicine (pengobatan jarak jauh), penyiapan dana darurat sector kesehatan untuk meminimalisir pembiayaan kesehatan. selain dari layanan kesehatannya, yang tak kalah penting adalah SDM yang ada dalam menangani kasus ini.

Peran tenaga kesehatan dalam mas covid-19 yaitu melakukan koordinasi lintas program di Puskesmas/ Fasilitas kesehatan dalam menentukan langkah-langkah menghadapi pandemic covid-19, melakukan analisis data dan mengidentifikasi kelompok sasaran berisiko yang 
memerlukan tindak lanjut, melakukan koordinasi kader, RT/RW/Kepala Desa/Kelurahan dan tokoh masyarakat setempat terkait sasaran kelompok berisiko dan modifikasi pelayanan sesuai kondisi wilayah, serta melakukan sosialisasi terintegrasi dengan lintas program lain kepada masyarakat tentang pencegahan penyebaran covid-19 (Kemenkes, 2020). Dalam hal ini, langkahlangkah dalam menyikapi pandemi ini berdampak langsung dalam hal pengembangan kompetensi SDM.

Selain itu, yang menjadi garda terdepan dalam menghadapi covid-19 ini adalah dokter dan perawat serta semua SDM yang ada di Rumah Sakit maupun pelayanan kesehatan beresiko terpapar virus tersebut. Dokter dan Perawat merupakan garda terdepan yang berhubungan/kontak langsung dalam menangani pasien. Pada kasus ini, rumah sakit memerlukan upaya pembinaan Keselamatan dan Kesehatan Kerja Rumah Sakit (K3RS). Strategi pencegahan kecelakaan kerja dan kontrol infeksi yang diterapkan oleh tenaga kesehatan adalah dengan lebih menekankan alat pelindung diri (APD) (Apriluana et al., 2016).

APD yang harus digunakan dalam mengatasi wabah ini antara lain masker N95, gaun, sarung tangan, pelindung mata, apron, dan sepatu boots. Kenyataannya, APD yang digunakan terkadang tidak sesuai. Masih terdapatnya rumah sakit /pelayanan kesehatan yang minim dengan APD bagi tenaga kesehatan. Selain APD, jumlah tenaga kesehatan yang terkait juga masih minim, bukan hanya dalam menangani kasus pandemi covid-19, sebelumnya tenaga kesehatan di Indonesia juga masih kuran dan penyebarannya tidak merata. SDM yang diharapkan adalah SDM yang kompeten, professional dan berdaya saing, karena dalam kasus ini tidak sedikit tenaga medis yang meninggal akibat wabah pandemi covid-19 (Kemenkes, 2020).

Pengendaliaan wabah covid-19 di Indonesia bukan hanya dilihat dari rumah sakit yang memadai serta SDM yang berkualitas, tetapi yang harus diperhatikan untuk menghadapi covid-19 ini yaitu sistem kesehatan mulai dari pemberian layanan kesehatan, tenaga kerja, sistem informasi, akses ke obat-obatan, pembiayaan layanan kesehatan, tenaga kerja, dan tata kelola layanan kesehatan.

\section{SIMPULAN}

Pandemi covid-19 ini sangat memiliki memiliki banyak dampak baik sosial maupun ekonomi. Dalam hal ini Indonesia telah berupaya untuk mengendalikan dan memutus mata rantai covid-19 dengan membuat dan menerapkan peraturan-peraturan yang berlaku. Namun, dalam menghadapi covid-19 ini, bukan hanya peran pemerintah dan peran tenaga kesehatan saja yang dapat diandalkan tetapi juga peran dan kesadaran dari masyarakat untuk dapat mengindahkan himbauan dari pemerintah maupun tenaga kesehatan serta meningkatkan kesadaran diri untuk mencegah penyebaran virus covid-19.

\section{DAFTAR PUSTAKA}

Apriluana, Gladys, Khairiyati, Laily, Setyaningrum, Ratna. (2016). Hubungan Antara Usia, Jenis Kelamin, Lama Kerja, Pengetahuan, Sikap dan Ketersediaan Alat Pelindung Diri (APD) dengan perilaku Penggunaan APD Pada Tenaga Kesehatan. Jurnal Publikasi Kesehatan Masyarakat Indonesia. 3(3), 1-7.

Buana, D. R. (2020). Analisis Perilaku Masyarakat Indonesia dalam Menghadapi Pandemi Virus Corona (Covid-19) dan Kiat Menjaga Kesejahteraan Jiwa. National Research Tomsk State University, Universitas Mercu Buana.

Djalante R, Lassa J, Setiamarga D, Sudjatma A, Indrawan M, Haryanto B, Mahfud G., et al. (2020). Review and Analysis of Current Responses to Covid-19 in Indonesia: Period of January to March 2020. Progress in Disaster Science, 100091, 1-9.

Dong Y, Mo X, Hu Y, et al. (2020). Epidemiology of Covid-19 Among Children in China. American Academy of Pediatrics, DOI: 10.1542/peds.20200702

Kementrian Kesehatan RI. (2020). Pedoman Pencegahan dan Pengendalian Coronavirus Disease. Direktorat Jenderal Pencegahan dan Pengendalian Penyakit, 1-136.

Kementerian Kesehatan Republik Indonesia. (2020). Info Infeksi Emerging Kementerian Kesehatan RI [Internet]. 2020 [updated 2020 March 30; cited 2020 March 31]. Available from: https://infeksiemerging.kemkes.go.id

Putri, R. N. (2019). Perbandingan Sistem Kesehatan di Negara Berkembang dan Negara Maju. Jurnal Ilmiah Universitas Batanghari Jambi, 19(1), 139146.

Ren L-L, Wang Y-M, Wu Z-Q, Xiang Z-C, Guo L, Xu $\mathrm{T}$, et al. (2020). Identification of a novel coronavirus causing severe pneumonia in human: a descriptive study. Chin Med J. 2020; published online February 11 . DOI: 10.1097/CM9.0000000000000722.

Sohrabi C, Alsafi Z, O’Neill N, et al. (2020). World Health Organization declares global emergency: A review of the 2019 novel coronavirus (COVID19). International Journal of Surgery. 76, 71-76.

Susilo A, Rumende, C. M, Pitoyo, C.W. (2020). Coronavirus Disease 2019: Review of Current Literatures. Jurnal Penyakit Dalam Indonesia. 7(1), 45-64.

Tosepu, R., Gunawan, J., Effendy, D.S., Ahmad, L.O.A.I., Lestari, H., Bahar, H., As fi an, P., (2020). Correlation between weather and Covid19 pandemic in Jakarta, Indonesia. Sci. Total Environ., 138436 https://doi.org/10.1016/j.scitotenv.2020.138436 
WHO. 26 March (2020). Critical Preparedness. Readliness and Response Actions for Covid-19.

World Health Organization, Novel Coronavirus (2019nCoV): Situation Report - 10, (2020). https://www.who.int/docs/defaultsource/coronaviruse/situation-reports/20200130sitrep-10ncov.pdf?sfvrsn=d0b2e480_2

World Health Organization, Novel Coronavirus (2019$\mathrm{nCoV}$ ) Advice for the Public,_(2020) https://www.who.int/emergencies/diseases/novelcoronavirus-2019/advice-for-public

Yuliana. (2020). Corona Virus Disease (Covid-19); Sebuah Tinjauan Literatur. Wellness and Healthy Magazine, 2(1), 187-192. 